\title{
ANAESTHESIA FOR CEREBRAL ARTERIOVENOUS MALFORMATIONS IN CHILDREN
}

\author{
M.E. MCLEOD, R.E. CReighton AND R.P. Humphreys
}

\begin{abstract}
Between 1966 and 1981, 46 patients underwent a total of 50 craniotomies for exploration and excision of cerebral arteriovenous malformations (AVMs) at The Hospital for Sick Children, Toronto. Thirty-three of these patients presented with intracranial haemorrhage, 13 of whom required emergency operations. Thirteen patients underwent elective surgery after investigation of a variety of medical complaints. In most cases, anaesthesia was induced with thiopentone followed by a muscle relaxant to facilitate intubation. Anaesthesia was maintained with nitrous oxide and oxygen, a muscle relaxant, halothane and/or an intravenous narcotic, and positive pressure ventilation. In 60 per cent of patients, blood loss was less than 20 per cent of estimated blood volume (EBV) although four children lost more than 50 per cent of their EBV. There were no deaths during operation. Controlled hypotension was employed in 30 operations to improve operating conditions during excision of deep-seated AVMs. Blood loss was similar in the non-hypotensive group, but these procedures tended to be of shorter duration. The advantages of various hypotensive techniques in children undergoing operations for cerebral AVMs are discussed and current anaesthetic management at The Hospital for Sick Children is described.
\end{abstract}

Key Words: ANaEsthesia, paediatric, neurosurgical; Anaesthetic TeChNIQUES, controlled hypotension; SURGERY, cerebral arteriovenous malformations.

AlTHOUGH cerebral arteriovenous malformations (AVMs) are cogenital lesions, they may give rise to symptoms at any time during childhood. There is often a need for urgent surgical intervention which presents several potential problems for the anaesthetist. In addition to the presence of an intracranial clot, which may be expanding, there is the risk of recurrent bleeding from the AVM during induction and the possibility of massive haemorrhage during dissection.

At the Hospital For Sick Children, Toronto, from 1966 to 1981, 50 operations were done on 46 paediatric patients for exploration and excision of intracranial arteriovenous malformations (AVMs), excluding those involving the great

M.E. McLeod, M.D., F.R.C.P.(C), Clinical Fellow, Department of Anaesthesia, The Hospital for Sick Children; R.E. Creighton, M.D., F.R.C.P.(C), Staff Anaesthetist, The Hospital for Sick Children, Associate Professor of Anaesthesia, University of Toronto; R.P. Humphreys, M.D., F.R.C.S.(C), Staff Neurosurgeon, The Hospital for Sick Children, Associate Professor of Surgery, University of Toronto, Toronto, Ontario, Canada.

Reprint requests to: Dr. R.E. Creighton, Department of Anaesthesia, The Hospital for Sick Children, 555 University Avenue, Toronto, Ontario MSG 1 X8.

Can. Anaesth. Soc. J., vol. 29, no. 4, July 1982 vein of Galen. This paper reviews the clinical presentation and anaesthetic management of these patients and describes our current anaesthetic practice.

\section{Clinical Presentation}

The ages of the patients at the time of operation ranged from four weeks to 16 years (Table I). Thirty-two patients were male and 14 female. Intracranial haemorrhage was the reason for admission of 33 ( 71.7 per cent) and led to emergency operations at the time of admission in 13. The other twenty patients with haemorrhage came to operation after several days of stabilization in the Intensive Care Unit. Neurological

TABLE I

Age at Time of Operation

\begin{tabular}{cc}
\hline Age (years) & No. of children \\
\hline$<1$ & 3 \\
$1-5$ & 7 \\
$6-10$ & 18 \\
$11-15$ & 19 \\
16 & 3 \\
\hline
\end{tabular}


status at the time of admission is expressed according to the subarachnoid grading system of Botterell $^{\mathrm{l}}$ (Table II).

The remaining 13 patients were operated on after investigation of medical complaints associated with their AVM. Eight had a seizure disorder, one of whom also had cardiac failure. Three patients had headache as the initial complaint, one presented with congestive heart failure, and one with developmental delay.

Four patients had a second elective operation after incomplete excision at the first procedure.

\section{Anaesthetic Management}

Anaesthesia was induced with thiopentone in 43 operations. In 16 of these patients, anaesthesia was deepened with an inhalation agent before tracheal intubation. Inhalation induction with nitrous oxide and halothane was used at four operations. Following induction, tracheal intubation was facilitated with a muscle relaxant and controlled hyperventilation was instituted. Two apnoeic patients were intubated without anaesthesia in the Emergency Department. Anaesthesia was maintained with nitrous oxide and oxygen, d-tubocurarine or pancuronium bromide, and a narcotic and/or halothane.

The remaining patient was managed with neuroleptanalgesia. This child, who presented with seizures, had a small previously unrecognized AVM, and was not intubated for the procedure.

\section{Control of Arterial Pressure}

Arterial blood pressure was reduced pharmacologically in 30 . operations. Pentolinium tartrate was used during ten, halothane for eight, trimethaphan camsylate in five, sodjum nitroprusside in five, and a combination of hydralazine and propranolol in two.

In seven instances more than one agent was employed. Halothane was added to further lower the blood pressure obtained with trimethaphan in four cases and pentolinium in two. The remaining patient received both pentolinium and nitroprusside in an attempt to reduce the necessary dosage of each.

During 20 operations no attempt was made to lower the systemic blood pressure. However, halothane 0.5 per cent was used for maintenance anaesthesia during 15 and intravenous Innovar ${ }^{\text {B }}$ was given during two operations.

\section{Blood Loss}

Blood losses were estimated by the following method. If we assume that the blood volume is constant, then:

Total haemoglobin (Hgb) lost

$=$ (total pre-operative $\mathrm{Hgb}$

+ total transfused $\mathrm{Hgb}$ )

- (total Hgb on first post-operative day).

The blood loss is expressed as a per cent of estimated blood volume (EBV) as follows:

$$
\frac{\text { total } \mathrm{Hgb} \text { lost }}{\text { total pre-op } \mathrm{Hgb}} \times 100=\text { per cent lost } \text {. }
$$

Adequate information was available for 45 operations. Blood loss was 20 per cent or less of estimated blood volume in 27 cases and 10 per cent or less in ten. In four cases it was greater than 50 per cent of estimated blood volume, actually exceeding 100 per cent in two.

The lowest blood pressure obtained differed significantly, depending on whether pharmacological lowering of blood pressure was attempted. If the four patients with blood loss greater than 50 per cent of estimated blood volume are excluded, blood loss did not differ significantly between the two groups (17.2 \pm 11.1 per cent of estimated blood volume in the hypotensive group and $18.6 \pm 12.0$ per cent in the non-hypotensive group) (Table III). These four patients are excluded because bleeding was catastrophic and not typical of the group as a whole. In one, a hypotensive technique was employed, but in two others massive haemorrhage occurred early in the procedure and resulted in circulatory arrest, so that use of controlled hypotension could not be considered. The fourth patient was in the non-hypotensive group. These four patients will be discussed further under complications during operation.

\section{COMPLiCATIONS DURING OPERATION}

One patient was apnoeic for 45 minutes after a single intravenous dose of succinylcholine. Another patient on controlled ventilation whose operation was carried out in the semi-sitting position had an air embolus when the power burr failed to lock and perforated the sagittal sinus. This was associated with a decrease in blood pressure to $9.3 \mathrm{kPa}(70 \mathrm{mmHg})$. The patient was immediately lowered to the reclining position 
TABLE II

Botterell Grading $^{5}$ of 33 Children with Intracranial HaEmorrhage FROM AVM

\begin{tabular}{|c|c|c|c|}
\hline Grade & Description & $\begin{array}{l}\text { Emergency } \\
\text { operations }\end{array}$ & $\begin{array}{c}\text { Semi-elective } \\
\text { operations }\end{array}$ \\
\hline I & $\begin{array}{l}\text { Conscious with ar without } \\
\text { signs of subarachnoid blood }\end{array}$ & 1 & 11 \\
\hline II & $\begin{array}{l}\text { Drowsy without significant } \\
\text { neurological deficit }\end{array}$ & 1 & 5 \\
\hline III & $\begin{array}{l}\text { Drowsy with a neurological } \\
\text { deficit }\end{array}$ & 3 & 4 \\
\hline IV & $\begin{array}{l}\text { Major neurological deficit and } \\
\text { deteriorating due to } \\
\text { intracerebral clot }\end{array}$ & 6 & 0 \\
\hline $\mathrm{V}$ & $\begin{array}{l}\text { Moribund patient with failing } \\
\text { vital centres }\end{array}$ & 2 & 0 \\
\hline
\end{tabular}

TABLE III

Operative Blood loss and Controlled Hypotension During Resection of Cerebral AVM

\begin{tabular}{lccc}
\hline & $\begin{array}{c}\text { Lowest systolic } \\
\text { blood pressure } \\
(\mathrm{kPa})\end{array}$ & $\begin{array}{c}\text { Blood loss as } \\
\% \text { of EBV }\end{array}$ & $\begin{array}{c}\text { Duration of } \\
\text { operation } \\
(\mathrm{min})\end{array}$ \\
\hline $\begin{array}{l}\text { Intracranial haemorrhage } \\
\text { Emergency surgery }\end{array}$ & & & \\
$\begin{array}{l}\text { a. with controlled } \\
\text { hypotension }\end{array}$ & $9.6 \pm 1.8$ & $25.2 \pm 19.5$ & $306 \pm 79$ \\
$\begin{array}{l}\text { b. without controlled } \\
\text { hypotension }\end{array}$ & $12.2 \pm 1.7$ & $18.1 \pm 16.0$ & $235 \pm 147$ \\
$\begin{array}{l}\text { Semi-elective surgery } \\
\text { a. with controlled } \\
\text { hypotension }\end{array}$ & $9.4 \pm 1.4$ & $16.2 \pm 9.2$ & $415 \pm 186$ \\
$\begin{array}{l}\text { b. without controlled } \\
\text { hypotension }\end{array}$ & $11.6 \pm 2.8$ & $16.0 \pm 8.2$ & $320 \pm 130$ \\
$\begin{array}{l}\text { Elective Surgery } \\
\text { a. with controlled } \\
\text { hypotension }\end{array}$ & $9.2 \pm 1.2$ & $17.1 \pm 7.5$ & $328 \pm 95$ \\
$\begin{array}{l}\text { b. without controlled } \\
\text { hypotension }\end{array}$ & $12.1 \pm 1.2$ & $17.4 \pm 10.3$ & $232 \pm 49$ \\
\hline
\end{tabular}

and given 100 per cent oxygen, and the venous tear was packed. The blood pressure returned to normal within five minutes and, after repair of the vascular defect, excision of the AVM proceeded uneventfully.

Massive bleeding (greater than 50 per cent of estimated blood volume) occurred in four patients. One, a four-week-old boy with a dural AVM, lost an estimated 249 per cent of his blood volume. His blood pressure was unobtainable for $\mathbf{1 0}$ minutes despite rapid transfusion. He was successfully resuscitated but the AVM was not completely resected. In the only other dural AVM 65 per cent of estimated blood volume was lost while the skull was being opened. Arrhythmia developed in this child, presumably due to hypovolaemia, and cardiac arrest occurred. After successful resuscitation the procedure was terminated and the patient was retumed to the operating room two weeks later for surgical excision. This procedure was uneventful and blood loss was 27 per cent of estimated blood volume.

Another patient lost 139 per cent of estimated 
blood volume during emergency surgery after an intracranial haemorrhage, although his systolic blood pressure remained above $10.6 \mathrm{kPa}$ (80 $\mathrm{mmHg}$ ).

The fourth patient, who had a cerebellar AVM extending into the brain stem, lost 60 per cent of his estimated blood volume during a long operation (13 hours and 20 minutes) under hypotension with halothane. When his blood pressure was restored to normal before operative closure, bleeding resumed. Pentolinium-induced hypotension to control the bleeding was continued for 48 hours post-operatively. The AVM was incompletely excised.

Another hypotensive complication occurred in a patient in whom hypotension was induced with pentolinium. The child required a phenylephrine infusion to return his blood pressure to $13.3 \mathrm{kPa}(100 \mathrm{mmHg})$ before surgical closure.

One patient became hypertensive to $21.9 \mathrm{kPa}$ $(160 \mathrm{mmHg}$ ) after a sodium nitroprusside infusion was discontinued. Post-operatively, an epidural haematoma developed that necessitated a second craniotomy for evacuation.

There were no deaths during operation. Two patients with massive cerebral haematomata died in the post-operative period, one at ten days, and one at two weeks, after a second intracranial haemorrhage.

\section{Discussion}

Cerebral AVMs are more likely to produce symptoms in children than are cerebral arterial aneurysms. From 1954 to 1981,86 patients were admitted to The Hospital for Sick Children because of symptoms arising from an intracranial AVM (aneurysms of the great vein of Galen excluded). During the same period only 26 children were admitted with cerebral arterial aneurysms.

Cerebral arteriovenous malformations arise from an imperfect formation of the primitive arteriolar-capillary network normally interposed between brain arteries and veins. The resultant tangle of arteriovenous communications, because of its low resistance, attracts an exaggerated blood flow. The number of fistulous connections does not change but, given time, the malformation may increase in size by enlarging and increasing the tortuosity of the feeding and draining channels. ${ }^{2}$

Spontaneous intracranial haemorrhage is the most common cause of symptoms experienced by children. ${ }^{3-5}$ The ictus is often explosive. The previously well child screams, complains of a sudden headache, then clasps the side of the head and collapses. Not surprisingly, the subarachnoid grading ${ }^{1}$ reflects the critical condition of the child at first assessment (Table II). Altered consciousness, meningismus and appropriate lateralizing motor and sensory signs are often present. Rapidly deepening stupor usually occurs when blood bursts into the ventricular system.

The sump effect of the direct arteriovenous anastomosis was presumably the cause of symptoms in the 13 patients ( 28 per cent) who did not present with intracranial haemorrhage. Ischaemia of the adjacent brain tissue may produce headache and, if chronic, can result in gliosis and epilepsy. Large AVMs can produce highoutput cardiac failure as in aneurysms of the vein of Galen.

The luxury of a planned, elective operation for a child with a ruptured cerebral AVM is often not realized. In this study, 33 patients ( 71.7 per cent) presented with intracerebral haemorrhage and 13 (28.2 per cent) required urgent neuroradiologic assessment and operative care. When only subarachnoid haemorrhage has occurred or when the intracerebral haematoma is small and the patient's condition stable, interval surgery may be staged after a few days' delay. The patient should be sedated and placed in a single room in the Intensive Care Unit. The advantage of this delay is that the patient will be properly prepared with a relaxed brain containing a liquifying haematoma. Cerebral vasospasm is seldom a problem in children with AVMs, but recurrence of bleeding during the interval frequently is.

There is not the same urgency for patients who present with symptoms other than spontaneous haemorrhage. Some cases will be diagnosed after traditional investigation of a medical complaint and others will be identified when postoperative investigation shows incomplete excision of the AVM at the first operation.

Controlled reduction of systemic blood pressure is often of benefit during cerebral AVM surgery in children. It is particularly beneficial when the AVM is deep-seated and difficult to approach or minor bleeding hampers dissection under the microscope. The feeding arteries of some AVMs are large and tense. These are more safely clipped after their intraluminal pressure is reduced.

There are two possible explanations for the fact that blood loss was not significantly lower in our hypotensive patients. First, the operations 
for which a hypotensive technique was chosen were of longer average duration, which suggests a more difficult dissection under the microscope. Second, the level of hypotension necessary is not as low for successful resection of cerebral AVMs as is usually required for cerebral arterial aneurysms.

The safe level and duration of controlled hypotension in children is not known. On the one hand the absence of arteriosclerosis should provide a greater margin of safety during systemic hypotension. On the other hand the cerebral blood flow and cerebral metabolic rate are higher in children who, therefore, seem more at risk from a reduction in cerebral blood flow and oxygen supply. ${ }^{8}$ The clinical impression is that children, particularly infants, tolerate systemic hypotension under anaesthesia better than adults.

The mechanism producing hypotension is important. In a study of baboons, Fitch, Ferguson, Sengupta, and Garibi ${ }^{9}$ showed that with hypotension due to adrenergic blocking agents (amongst which they include halothane), autoregulation persisted to a mean arterial blood pressure (MABP) of $4.7 \mathrm{kPa}(35 \mathrm{mmHg})$. In baboons with hypotension due to haemorrhage, autoregulation persisted only to a mean arterial blood pressure of $8.6 \mathrm{kPa}(65 \mathrm{mmHg})$.

Michenfelder and Theye ${ }^{10}$ concluded that hypotension induced by halothane or nitroprusside appears to be superior to that produced by trimethaphan or haemorrhage in dogs with marginal perfusion pressures. Bain, Catton, Cox, and Spoerel ${ }^{11}$ concluded that halothane had a beneficial effect on rabbits exposed to cerebral ischaemia.

Stone, Connelly, Mackrell, Brandstater, and Nemir ${ }^{12}$ demonstrated that respiratory alkalosis $\left(\mathrm{Paco}_{2} 2.8 \mathrm{kPa}\right.$ [21 $\left.\mathrm{mmHg}\right]$ ) exacerbates the cerebral hypoxia produced by hypovolaemic hypotension by modifying the compensatory cerebral vascular dilatation.

The prudent course is to lower the systemic blood pressure only to the level required for successful surgery. Reduction of the mean arterial blood pressure below $6.7 \mathrm{kPa}(50 \mathrm{mmHg})$ should be as brief as possible. Severe respiratory alkalosis $\left[\mathrm{Paco}_{2}\right.$ below $\left.4.0 \mathrm{kPa}(30 \mathrm{mmHg})\right]$ should not be employed.

If a hypotensive technique is chosen several agents are available, each with advantages and disadvantages. Halothane has the advantage of ready reversibility by rapid removal through the lungs. Since the patients are hyperventilated and the cranium is open, the increased cerebral blood flow does not present a problem.

Pentolinium tartrate has the advantage that a continuous intravenous infusion is not required. Our technique is to administer 1-2 mg intravenously and follow with $1 \mathrm{mg}$ every five minutes until the blood pressure ceases to fall, or until the desired blood pressure level is achieved. In some patients the level desired will not be achieved and halothane must be added to the anaesthetic mixture for further reduction. The major advantage of pentolinium is that once the desired blood pressure level is reached it is quite stable. Further decreases in blood pressure are due to hypovolaemia and are countered with blood transfusion. Since pentolinium is a ganglion blocking agent, rapid reversal of hypotension can be achieved by the use of alpha-stimulating agents such as phenylephrine. The pupils may remain dilated in post-operative period.

The main advantage of sodium nitroprusside is the rapid reduction of blood pressure after administration and the rapid retum of blood pressure after cessation. If the recommended maximum dose $\left(8 \mu \mathrm{g} \cdot \mathrm{kg}^{-1} \cdot \mathrm{min}^{-1}\right)$ is not exceeded cyanide poisoning is not likely to be a problem. ${ }^{13}$ Rebound of blood pressure to higher than normal levels may be seen after administration.

We have not had as much success with trimethaphan camsylate. There is a greater tendency for tachyphylaxis and halothane must often be added to obtain the desired degree of hypotension.

Hydralazine has been an unreliable drug for controlled hypotension in our experience and propranolol must be given to counteract the compensatory tachycardia which accompanies its use during operation.

\section{Current Anaesthetic Management}

Anaesthesia for patients with intracranial haemorrhage presents three major problems to the anaesthetist. First, the patient may be unconscious, necessitating immediate airway support and controlled ventilation. Second, he may have an expanding intracranial haematoma. Third, systemic hypertension may re-initiate or exacerbate intracranial bleeding. If intubation is required for resuscitation and/or neuroradiological investigation, the technique should be designed to minimize the systemic hypertension normally associated with tracheal intubation under light anaesthesia. ${ }^{14}$ All patients, even the unconscious, should receive thiopentone $5 \mathrm{mg} \cdot \mathrm{kg}^{-1}$ 
intravenously before intubation. Intravenous lidocaine $1.5 \mathrm{mg} \cdot \mathrm{kg}^{-1}$ has been recommended at this time. ${ }^{15,16}$ In an emergency, because of the danger of a full stomach, tracheal intubation should be preceded by pre-oxygenation and a rapid sequence induction and should be carried out while cricoid pressure is applied.

Patients scheduled for elective surgery should be premedicated. We administer Innovar ${ }^{\sqrt{6}}$ $0.04 \mathrm{ml} \cdot \mathrm{kg}^{-1}$ intravenously before departure for the operating room. If sedation is considered inadequate after five minutes, half of the original dose of Innovar is repeated. In the anaesthetic induction room we prefer intravenous induction with thiopentone, deepening of the anaesthetic level with nitrous oxide, oxygen and halothane for eight minutes and then tracheal intubation facilitated by pancuronium bromide $0.15 \mathrm{mg} \cdot \mathrm{kg}^{-1}$ or d-tubocurarine $0.6 \mathrm{mg} \cdot \mathrm{kg}^{-1}$.

We prefer an armoured orotracheal tube for operations in the supine or lateral position. For prone patients we choose a nasotracheal tube which is unlikely to become kinked and has less danger of accidental extubation after the fixation tape is loosened by secretions.

Dexamethasone $0.15 \mathrm{mg} \cdot \mathrm{kg}^{-1}$ is administered intravenously as well as a diuretic, either furosemide $0.8 \mathrm{mg} \cdot \mathrm{kg}^{-1}$ or 20 per cent mannitol $2 \mathrm{gm} \cdot \mathrm{kg}^{-1}$ over one hour.

Anaesthesia is maintained with nitrous oxide, oxygen and either halothane 0.5 per cent or repeated doses of fentanyl $0.002 \mathrm{mg} \cdot \mathrm{kg}^{-1}$. Additional non-depolarizing muscle relaxants are administered as indicated by a nerve stimulator. The patient is positioned with the head of the table raised 15 degrees and the ventilator is adjusted to give a $\mathrm{Paco}_{2}$ of $3.99 \mathrm{kPa}(30 \mathrm{mmHg})$ confirmed by blood gas analysis.

Patient monitors consist of oesophageal stethoscope for breath and heart sounds; electrocardiograph for cardiac rate, rhythm, and conduction; appropriately sized blood pressure cuff and Doppler probe for blood pressure; indwelling arterial cannula in the radial or dorsalis pedis artery for blood pressure and arterial blood gas analysis; indwelling urinary catheter; rectal thermister probe. A central venous line may be helpful particularly for patients in whom massive blood loss is anticipated. However it is often difficult to insert the central venous line from the antecubital fossa in a small patient and after insertion the position must be verified by a pressure recording, electrocardiograph, or roentgenograph. A precordial Doppler is indicated in patients operated upon in the semi-sitting posi- tion. We do not routinely position a right heart catheter.

At present our decision to use controlled hypotension depends on the preoperative neuroradiological assessment. If the position of the AVM or the appearance of the vessels suggests that moderate systemic hypotension would be beneficial, pentolinium tartrate is administered after the operation has started. Similarly, if the systolic blood pressure remains above $13.3 \mathrm{kPa}$ $(100 \mathrm{mmHg})$ after the operation has started, despite the addition of 0.5 per cent halothane to the anaesthetic mixture, pentolinium tartrate is administered. If a short period of hypotension is required during the resection, halothane or sodium nitroprusside is employed.

Fluids are administered during the operation as follows. When furosemide is the diuretic, urine is collected and losses above 10 per cent of estimated blood volume are replaced with a solution of 5 per cent dextrose and 0.2 per cent saline. When 20 per cent mannitol is the diuretic, this fluid is administered only after the volume of urine exceeds 10 per cent of the estimated blood volume plus the volume of mannitol infused.

For patients in whom controlled hypotension is not required the systolic blood pressure is allowed to fall to $10.0 \mathrm{kPa}(75 \mathrm{mmHg})$. Thereafter it is kept at this level with blood transfusions. Before closure enough blood is transfused to return the systolic blood pressure to its preloss value and then blood equal to ten per cent of the estimated blood volume is transfused during the closure. Some patients will not require blood transfusion during operation. These patients receive lactated Ringer's solution $10 \mathrm{ml} \cdot \mathrm{kg}^{-1}$ during the closure.

\section{SUMMARY}

From 1966 to 1981,50 operations were done at The Hospital for Sick Children, Toronto, for exploration and excision of intracranial arteriovenous malformations in 46 patients. Intracranial haemorrhage was the reason for admission of 33 , of whom 13 required emergency surgery. Other complaints including seizure disorder, headache, congestive heart failure and delayed development were the reason for admission of 13 patients.

In most patients anaesthesia was induced with intravenous thiopentone and tracheal intubation was facilitated with muscle relaxant. Anaesthesia was maintained with nitrous oxide and intravenous narcotic and/or halothane 0.5 per 
cent and ventilation was controlled in all but one operation. One patient with an unrecognized small AVM was managed with neuroleptanalgesia.

The systemic blood pressure was reduced with a variety of agents during 30 operations. While this systemic hypotension did not decrease operative blood loss, operating conditions were improved. Complications during operation included blood loss greater than 50 per cent of the estimated blood volume in four patients, circulatory arrest in two, air embolism in one patient, and succinylcholine apnoea in one. Patients with dural AVMs were particularly likely to have massive blood loss during operation.

Our current anaesthetic management is based on our experience with these patients. Premedication is important in the elective or semi-elective cases and should be followed by a smooth induction using thiopentone, intravenous lidocaine, muscle relaxant, and an inhalation agent before tracheal intubation. Patients are hyperventilated to $\mathrm{PCO}_{2}$ of $3.99 \mathrm{kPa}$ and anaesthesia is maintained with nitrous oxide, oxygen, nondepolarizing muscle relaxant, and fentanyl or an inhalation agent. The use of pharmacologically induced hypotension depends on the surgical assessment of the size and position of the lesion.

\section{REFERENCES}

1. Botterelt, E.H., Lougheed, W.M., SCOTt, J.W. \& VANDERWATER, S.L. Hypothermia and interruption of carotid, or carotid and vertebral circulation, in the surgical management of intracranial aneurysms. J. Neurosurg. 13: 1 (1956).

2. Drake, C.G. Cerebral arteriovenous malformations: considerations for and experience with surgical treatment in 166 cases. Clin. Neurosurg. 26: 145 (1979).

3. Matson, D.D. Neurosurgery of Infancy and Childhood. 2nd ed. Springfield: Chas. C. Thomas pp. 749-766, (1969).

4. So, S.C. Cerebral arteriovenous malformations in children. Child's Brain 4: 242 (1978).

5. Mori, K., Murata, T., Hashimoto, N. \& HaNDo, H. Clinical analysis of arteriovenous malformation in children. Child's Brain 6: 13 (1980).

6. Perret, G. \& Nishioka, H. Report on the Co-operative Study of Intracranial Aneurysms and Subarachnoid Hemorrhage. Section VI Arteriovenous malformations. J. Neurosurg. 25: 467 (1966).

7. Russell, D.S. \& Rubinstein, L.J. Pathology of Tumours of the Nervous System. 4th ed. London: Edward Amold pp. 136-138 (1977).

8. KeNNEDY, C. \& SOKOLOFF, L. An adaptation of the nitrous oxide method to the study of the circulation in children; normal values for cerebral blood flow and cerebral metabolic rate in childhood. J. Clin. Invest. 36: 1130 (1957).

9. Fitch, W., Ferguson, G.G., Sengupta, D. \& GaRIBI, J. Autoregulation of cerebral blood flow during controlled hypotension. Stroke 4: 324 (1973) (Abstract).

10. Michenfelder, J.D. \& Theye, R.A. Canine systemic and cerebral effects of hypotension induced by hemorrhage, trimethaphan, halothane, or nitroprusside. Anesthesiology 46:188 (1977).

11. Bain, J.A., Catton, D.V., Cox, J.M.R. \& SPOEREL, W.E. The effect of general anaesthesia on the tolerance of cerebral ischaemia in rabbits. Can. Anaesth. Soc. J. 14: 69 (1967).

12. Stone H.H., Connelly, C.C., Mackrell, T.N., Brandstater, B.J. \& Nemir, P. JR. The effect of acute hemornhagic shock on cerebral circulation and metabolism of man. In Shock and Hypotension: Pathogenesis and Treatment. Edited by L.C. Mills \& J.H. Moyer, New York: Grune and Stratton pp. 257-264 (1965).

13. MiChenfelder, J.D. \& Tinker, J.H. Cyanide toxicity and thiosulfate protection during chronic administration of sodjum nitroprusside in the dog: comelation with a human case. Anesthesiology 47: 441 (1977).

14. KING, B.C., HaRris, L.C. JR., Greifenstein, F.E., ELDER, J.D. JR. \& DRIPPS, R.D. Reflex circulatory responses to direct laryngoscopy and tracheal intubation performed during general anesthesia. Anesthesiology 12: 556 (1951).

15. StOELTING, R.K. Circulatory changes during direct laryngoscopy and tracheal intubation: influence of duration of laryngoscopy with or without prior lidocaine. Anesthesiology 47: 381 (1977).

16. Bedford, R.F., Persing, J.A., Probereskin, L. \& BuTLER, A. Lidocaine or thiopentone for rapid control of intracranial hypertension? Anest. Analg. (Cleve.) 59: 435 (1980).

\section{Résumé}

Entre 1966 et 1981, 46 patients ont subis un total de 50 craniotomies pour exploration et excision de malformations cérébrales artérioveineuses au Hospital for Sick Children de Toronto. Trente-trois de ces patients avaient été admis à l'hôpital pour un hémorragie intra-crânienne et 13 parmi ceux-ci ont dî subir une intervention d'urgence. Treize patients ont été soumis à une chirurgie réglée après investigation. Dans la plupart des cas l'induction a été effectuée avec du thiopentone suivit d'un myorésolutif pour faciliter l'intubation. L'anesthésie a été maintenue au protoxyde d'azote-oxygène, un myorésolutif, de 
I'halothane avec ou sans narcotique intra-veineux et la ventilation assurée par pression positive intermittente. Dans 60 pour cent des cas, la perte sanguine a été moins de 20 pour cent du volume sanguin prédit, mais quatre patients ont perdu plus de 50 pour cent de leur volume sanguin. Il n'y a pas eu de mortalité per-opératoire. On a utilisé l'hypotension contrôlée dans 30 interventions pour améliorer les conditions opératoires pendant l'excision de malformations artério-veineuses situées profondément. Le perte sanguine a été la même que les patients non-soumis à l'hypotension mais la durée de l'intervention a été moindre. Les avantages des techniques hypotensives pour les enfants soumis à la chirurgie pour malformations arterio-veineuses cérébrales sont discutées et on décrit la technique anesthésique d'usage courant à l'hôpital pédiatrique de Toronto. 